\title{
Evaluation of powdery mildew-resistance of grape germplasm and rapid amplified polymorphic DNA markers associated with the resistant trait in Chinese wild Vitis
}

\author{
J. Zhang ${ }^{1,2,3}$, Y. Zhang ${ }^{1,2,3}$, H. Yu ${ }^{1,2,3}$ and Y. Wang ${ }^{1,2,3}$ \\ ${ }^{1}$ College of Horticulture, Northwest A\&F University, Yangling, \\ Shaanxi, China \\ ${ }^{2}$ Key Laboratory of Biology and Genetic Improvement of Horticultural Crops \\ in Northwest China, Ministry of Agriculture of China, Yangling, \\ Shaanxi, China \\ ${ }^{3}$ State Key Laboratory of Crop Stress Biology in Arid Areas, \\ Northwest A\&F University, Yangling, Shaanxi, China \\ Corresponding author: Y. Wang \\ E-mail: wangyj@nwsuaf.edu.cn
}

Genet. Mol. Res. 13 (2): 3599-3614 (2014)

Received March 23, 2013

Accepted September 24, 2013

Published May 9, 2014

DOI http://dx.doi.org/10.4238/2014.May.9.3

\begin{abstract}
The resistance of wild Vitis germplasm, including Chinese and American wild Vitis and Vitis vinifera cultivars, to powdery mildew (Uncinula necator Burr.) was evaluated for two consecutive years under natural conditions. Most of the Chinese and North American species displayed a resistant phenotype, whereas all of the European species were highly susceptible. The Alachua and Conquistador accessions of Vitis rotundifolia species, which originated in North America, were immune to the disease, while Baihe-35-1, one of the accessions of Vitis pseudoreticulata, showed
\end{abstract}


the strongest resistance among all Chinese accessions evaluated. Three rapid amplified polymorphic DNA (RAPD) markers, OPW02-1756, OPO11-964, and OPY13-661, were obtained after screening 520 random primers among various germplasm, and these markers were found to be associated with powdery mildew resistance in Baihe-35-1 and in some Chinese species, but not in any European species. Analysis of $F_{1}$ and $F_{2}$ progenies of a cross between resistant Baihe-35-1 and susceptible Carignane ( $V$. vinifera) revealed that the three RAPD markers were linked to the powdery resistant trait in Baihe-35-1 plants. Potential applications of the identified RAPD markers for gene mapping, marker-assisted selection, and breeding were investigated in $168 \mathrm{~F}_{2}$ progenies of the same cross. Characterization of the resistant phenotype of the selected $\mathrm{F}_{2}$ seedlings for breeding a new diseaseresistant grape cultivar is in progress.

Key words: Grape germplasm; Chinese wild Vitis; Powdery mildew; Disease resistance; RAPD marker

\section{INTRODUCTION}

Grape powdery mildew is an important agronomical disease that is caused by the fungal species Uncinula necator Burr. The disease has been reported in grape production areas worldwide (Alleweldt et al., 1990; Roy and Ramming, 1990; He et al., 1991; Gee et al., 2000; Akkurt et al., 2007; Belhadj et al., 2008). Major commercial grape cultivars with high fruit quality are usually derived from the species Vitis vinifera L. through genetic crossing; however, this species is highly susceptible to infection by the powdery mildew pathogen (Boubals, 1961; Alleweldt et al., 1990; Pearson and Gadoury, 1991; Li and Zhang, 1992; Dalbó et al., 2001; Pauquet et al., 2001; Barker et al., 2005; Belhadj et al., 2008). In vineyards, the powdery mildew disease is primarily controlled by fungicide applications. However, heavy applications of fungicide pollute the environment, potentially affecting the safety of grape berries for consumption due to remaining fungicide residues. Frequently, fungicide application also increases selective pressures that likely facilitate the evolution of more resistant strains in the field. Therefore, the development and use of host resistant strains through genetic crosses and breeding would be an effective and more environmentally friendly strategy to comprehensively control powdery mildew disease.

In nature, highly resistant traits have evolved in various grape species derived from different parts of the world. For example, almost all grape species native to North America are, to various degrees, inherently resistant to powdery mildew disease (Boubals, 1961; Alleweldt et al., 1990; He and Luo, 1994; Reisch and Pratt, 1996; Staudt, 1997; Pauquet et al., 2001; Barker et al., 2005; Hoffmann et al., 2008). However, due to genomic variation in chromosome numbers, introgression of the resistant trait from Vitis rotundifolia into the high fruit quality cultivars derived from $V$. vinifera is extremely difficult (Lu et al., 2000). Moreover, Vitis species native to North America have relatively poor fruit quality. These genetic barriers impede the rapid development of new cultivars with high fruit quality and powdery mildew resistance. High levels of powdery mildew resistance have also been found 
in some Vitis species native to China (He and Ren, 1990; He et al., 1991; Wang et al., 1995; Wang et al., 1998; Zhang et al., 2002; Wan et al., 2007), one of the major regions from which Vitis species originated (He et al., 1991). The major sources of powdery mildew resistance were found in wild Chinese Vitis species from across the country; however, most of these species are associated with poor fruit quality, an undesired trait for grape production. Unlike North American germplasm such as Vitis labrusca, these wild Chinese Vitis species have no foxy flavor and can be easily crossed with $V$. vinifera without genetic barriers, making the wild Chinese Vitis germplasm attractive candidates for genetic improvement of disease resistance in existing high fruit quality grape cultivars.

Despite numerous reports on the characterization of powdery mildew resistance in grape germplasm, the nature of resistance and linkage of genetic and molecular markers with resistance remains relatively unknown, especially in wild Chinese Vitis species. Selection for germplasm and hybrids based on phenotype is a time consuming process of plant cross breeding, whereas molecular markers allow for direct selection of favorable genotypes. As a valuable tool for genetic studies, random amplified polymorphic DNA (RAPD) technology has several distinct advantages: the procedure is simple, a very low amount of DNA is required for analysis, reaction costs are low, and the technology is faster and easier than amplified fragment length polymorphism (AFLP) or simple sequence repeat (SSR) analyses. Therefore, RAPD has been widely applied in grapevine genetic analyses (Weeden et al., 1994; Wang et al., 1996; Dalbó et al., 2001; Luo et al., 2002; Akkurt et al., 2007; Ercisli et al., 2008; Hoffmann et al., 2008). In this study, we comprehensively evaluated the powdery mildew resistant trait under natural conditions in wild Chinese Vitis, wild American Vitis, $V$. vinifera, and in interspecific hybrid $\mathrm{F}_{1}$ and $\mathrm{F}_{2}$ progenies derived from a cross between wild Chinese Vitis pseudoreticulata Baihe-35-1 and the V. vinifera cultivar Carignane. Furthermore, RAPD markers were developed and identified that were associated with the powdery mildew-resistant trait in $V$. pseudoreticulata Baihe-35-1. The identified RAPD markers were analyzed among the interspecific hybrid $\mathrm{F}_{2}$ progenies in order to explore the application of the markers for marker-assistant selection breeding programs.

\section{MATERIAL AND METHODS}

\section{Plant materials and powdery mildew-resistance identification}

The grape materials used in this study included 23 accessions of nine wild Chinese Vitis species, 11 accessions of nine wild American Vitis species, 14 cultivars of $V$. vinifera (Table 1), seven individuals of the interspecific hybrid $\mathrm{F}_{1}$ generation, and 207 individuals of the $\mathrm{F}_{2}$ generation derived from Baihe-35-1 ( $V$. pseudoreticulata) x Carignane ( $V$. vinifera) (Table 2 to Table 6). Baihe-35-1, which served as one of the parents in the cross population, has been found to be the most resistant to powdery mildew among all native Chinese grape germplasms (Wang et al., 1995; Wang and He, 1997; Zhang et al., 2002). The $\mathrm{F}_{1}$ progenies 6-12-1, 6-12-2, 6-12-3, 6-12-4, 6-12-5, 6-12-6, and 6-12-7 were derived from interspecific hybridization between Baihe-35-1 and Carignane in 1987. The $207 \mathrm{~F}_{2}$ individuals resulted from self-crossing of each of the $\mathrm{F}_{1}$ individuals 6-12-1, 6-12-2, 6-12-4, and 6-12-6 in 2001. These materials are maintained in the grape nursery of the Northwest Agriculture and Forestry University in China. 
Table 1. Resistance to powdery mildew and demonstration of RAPD markers in grape resources.

\begin{tabular}{|c|c|c|c|c|c|c|c|}
\hline Species & $\begin{array}{l}\text { Accessions or } \\
\text { varieties }\end{array}$ & $\begin{array}{l}\text { Susceptibility } \\
\text { index (SI) }\end{array}$ & $\begin{array}{c}\text { Resistance } \\
\text { level }\end{array}$ & Phenotype & OPW02-1756 & OPO11-964 & OPY13-661 \\
\hline V.pseudoreticulata & Baihe-35-1 & 7.23 & 3 & $\mathrm{R}$ & + & + & + \\
\hline \multirow[t]{8}{*}{ W.T. Wang } & Baihe-35-2 & 34.29 & 4 & $\mathrm{~s}$ & - & + & + \\
\hline & Baihe-13 & 18.79 & 3 & $\mathrm{R}$ & + & - & + \\
\hline & Baihe-13-1 & 18.67 & 3 & $\mathrm{R}$ & + & - & + \\
\hline & Guangxi-1 & 16.36 & 3 & $\mathrm{R}$ & - & - & + \\
\hline & Guangxi-2 & 30.36 & 4 & $\mathrm{~s}$ & - & - & + \\
\hline & Shangnan-1 & 28.93 & 4 & $\mathrm{~S}$ & - & - & - \\
\hline & Shangnan-2 & 30.93 & 4 & $\mathrm{~s}$ & - & - & + \\
\hline & Hunan-1 & 67.07 & 5 & HS & - & - & + \\
\hline \multirow[t]{2}{*}{ V. davidii Foex. } & Xuefeng & 11.23 & 3 & $\mathrm{R}$ & - & - & - \\
\hline & Tangwei & 10.50 & 3 & $\mathrm{R}$ & - & + & + \\
\hline V. ficifolia Bunge & Weinan-3 & 8.67 & 3 & $\mathrm{R}$ & & - & + \\
\hline V.quinquangularis & Taishan-12 & 12.83 & 3 & $\mathrm{R}$ & & - & + \\
\hline \multirow[t]{3}{*}{ Rehd. } & Shangnan-24 & 11.05 & 3 & $\mathrm{R}$ & - & + & + \\
\hline & 83-4-96 (†) & 14.44 & 3 & $\mathrm{R}$ & + & + & - \\
\hline & Danfeng-2 & 15.51 & 3 & $\mathrm{R}$ & & + & + \\
\hline \multirow[t]{3}{*}{ V. amurensis Rupr. } & Tonghua-3 & 21.00 & 3 & $\mathrm{R}$ & - & - & + \\
\hline & Zuoshan-2 & 23.69 & 3 & $\mathrm{R}$ & + & + & + \\
\hline & Heilongjiang Seedling & 24.25 & 3 & $\mathrm{R}$ & & + & + \\
\hline V. yeshanensis J.C. Chen & Yanshan-1 & 40.30 & 4 & $\mathrm{~s}$ & - & - & - \\
\hline V. piasezkii Maxim. & Gansu-91 & 39.14 & 4 & $\mathrm{~s}$ & - & - & - \\
\hline V. thunbergii Sieb. et Zucc. & Taishan-1 & 37.23 & 4 & $\mathrm{~s}$ & - & - & - \\
\hline V. qinlingensis P.C. He & Pingli-5 & 32.98 & 4 & $\mathrm{~s}$ & - & - & - \\
\hline \multirow[t]{2}{*}{ V. rotundifolia Michx. } & Alachua & 0 & 1 & IS & - & - & - \\
\hline & \multirow[t]{2}{*}{ Conquistador } & 0 & 1 & IS & - & - & - \\
\hline V. riparia Michx. & & 18.00 & 3 & $\mathrm{R}$ & - & - & + \\
\hline V. californica Benth. & \multirow[t]{2}{*}{ Gold Hill"1 } & 15.86 & 3 & $\mathrm{R}$ & + & - & - \\
\hline V. champini Planch. & & 11.86 & 3 & $\mathrm{R}$ & + & - & - \\
\hline V. rupestris Scheele & \multirow[t]{2}{*}{ A. De Serres } & 6.15 & 3 & $\mathrm{R}$ & - & - & - \\
\hline V. berlandieri Planch. & & 8.00 & 3 & $\mathrm{R}$ & - & - & - \\
\hline V. labrusca L. & \multirow[t]{3}{*}{ Y157 (Y18-95) } & 19.09 & 3 & $\mathrm{R}$ & - & - & - \\
\hline V. arizonica Engelm. & & 9.50 & 3 & $\mathrm{R}$ & + & - & - \\
\hline V. cinerea Engelm. & & 12.57 & 3 & $\mathrm{R}$ & + & - & - \\
\hline \multirow[t]{12}{*}{ V. vinifera $\mathrm{L}$. } & Carignane & 49.27 & 4 & $\mathrm{~S}$ & - & - & - \\
\hline & Riesling & 44.43 & 4 & $\mathrm{~S}$ & - & - & - \\
\hline & May Purple & 28.36 & 4 & $\mathrm{~S}$ & - & - & - \\
\hline & Chein Blanc & 42.50 & 4 & $\mathrm{~s}$ & - & - & - \\
\hline & Muscat Rose & 39.14 & 4 & $\mathrm{~S}$ & - & - & - \\
\hline & Muscat Blanc & 41.36 & 4 & $\mathrm{~s}$ & - & - & - \\
\hline & Muscat Hamburg & 57.43 & 5 & $\mathrm{HS}$ & - & - & - \\
\hline & Blue French & 85.00 & 5 & HS & - & - & - \\
\hline & Ugni Blanc & 71.78 & 5 & HS & - & - & - \\
\hline & Dalihong Seedless & 52.39 & 5 & HS & - & - & - \\
\hline & Jingkejing & 66.84 & 5 & HS & - & - & - \\
\hline & Black Rose & 61.24 & 5 & HS & - & - & - \\
\hline
\end{tabular}

IS = insusceptible, the resistance level is class $1 ; \mathrm{HR}=$ high resistance, class $2 ; \mathrm{R}=$ resistance, class $3 ; \mathrm{S}=$ susceptible, class 4 ; HS $=$ high susceptible, class $5 ;(+)=$ present for genes marker, $(-)=$ absent for genes marker. (The same as below).

The presence of powdery mildew resistance was evaluated in all tested plants between July and August in 2004 and 2005, respectively, under field conditions, since powdery mildew symptoms become fully developed between July and August. A total of 100 leaves from each clone were randomly surveyed, and symptoms in each leaf sample were scored in eight categories $(0,1,2,3,4,5,6$, and 7$)$, which corresponded to the estimated percentage of lesions in the entire leaf area $(0,0.1-5.0,5.1-15.0,15.1-30.0,30.1-45.0,45.1-65.0,65.1-85.0$, and above 85.0), respectively. A score of zero represents the most resistant phenotype, whereas a score of seven represents the most susceptible phenotype. The scores were converted to a susceptibility index: 
$\mathrm{SI}=[($ Sum of grade value $\mathrm{x}$ Number of leaves in that grade $) /($ Total leaf number $\mathrm{x}$ Highest grade value)] $x$ 100. The average SI across the two years was used as the final SI of each clone. The resistance level of each clone was classed within five classes based on its SI: Insusceptible (IS), $\mathrm{SI}=0$, class 1; High resistance $(\mathrm{HR}), \mathrm{SI}=0.1-0.5$, class 2; Resistance $(\mathrm{R}), \mathrm{SI}=5.1-25.0$, class 3; Susceptible (S), SI = 25.1-50, class 4; Highly susceptible (HS), SI = 50.1-100, class 5 .

\section{RAPD analysis}

Genomic DNA was isolated from young grapevine leaves using the CTAB method as described by Wang et al. (1996). The polymerase chain reaction (PCR) was run in a total $25 \mu \mathrm{L}$ volume, containing $500 \mathrm{mM} \mathrm{KCl}, 100 \mathrm{mM}$ Tris- $\mathrm{HCl}$, pH 9.0, 1\% Triton X-100, $1.5 \mathrm{mM} \mathrm{MgCl}_{2}$, $0.2 \mathrm{mM}$ each dNTP, $0.15 \mu \mathrm{M}$ primer, $45 \mathrm{ng}$ genomic DNA, and 1 U Taq DNA polymerase (Hua Mei Co. Luoyang, China). The amplification was performed in a DNA thermal cycler (Model PTC-100, Gene Co.) for pre-denaturation at $94^{\circ} \mathrm{C}$ for 5 min followed by 45 cycles of $1 \mathrm{~min}$ at $94^{\circ} \mathrm{C}, 1 \mathrm{~min}$ at $36^{\circ} \mathrm{C}$, and $2 \mathrm{~min}$ at $72^{\circ} \mathrm{C}$, with a final extension step at $72^{\circ} \mathrm{C}$ for $10 \mathrm{~min}$. The amplification products were separated by electrophoresis on $1.2 \%$ agarose gels containing 0.5 $\mu \mathrm{g} / \mathrm{mL}$ ethidium bromide in $1 \mathrm{X}$ TAE buffer (40 mM Tris-acetate, $\mathrm{pH} 8.0,1 \mathrm{mM}$ EDTA) at 120 $\mathrm{V}$ for $1 \mathrm{~h}$. In all cases, the DNA marker was used as the size marker. The gel was examined and photographed on a UV-light box. All reactions were repeated at least three times.

\section{Linkage analysis for RAPD markers linked to powdery mildew-resistant genes}

To obtain specific primers, 520 random primers were initially screened with the resistant parent Baihe-35-1 and the susceptible parent Carignane as well as with their $\mathrm{F}_{1}$ resistant (6-12-6) and susceptible (6-12-2) progenies. The linkage between the identified RAPD markers and powdery mildew resistance was roughly established through analysis of $F_{1}$ and $F_{2}$ (6-12-6 selfing) segregation populations of crosses between Baihe-35-1 and Carignane, and was then further verified in wild Chinese Vitis, V. vinifera, and wild American Vitis plants or germplasms. The map distances and associations were analyzed using data from 39 progenies of the 6-12-6 selfing population with the Joinmap version 4.0 software.

\section{Cloning and sequencing of RAPD products}

The amplified RAPD marker fragments were excised, purified using the DNA agarose gel cleanup kit (Tian Wei Shi Dai Biotechnology Co. Beijing, China), and cloned into the pGEM-T easy vector (Promega, USA). Several positive clones of each selected fragment were isolated and sequenced by the Shanghai Sangon Company. The marker sequences of a 1756-bp fragment amplified by the primer OPW02, a 964-bp fragment by the OPO11 primer, and a 661-bp fragment by the OPY13 primer were deposited in the GenBank database under the accession numbers AY491396, DQ493890, and DQ493892, respectively.

\section{Marker detection in the $F_{2}$ generation of Baihe-35-1 $x$ Carignane using the three specific primers}

To verify the three RAPD markers in accordance with the resistance phenotype under 
field conditions, RAPD analysis was performed with selfing progenies from $\mathrm{F}_{1}$ plants 6-12-1, 6-12-2, and 6-12-4 using the three specific primers OPW02, OPO11, and OPY13, respectively. The method for RAPD analysis was identical to that described above.

\section{RESULTS}

\section{Evaluation of powdery mildew resistance performance in Chinese grape germplasm}

Various accessions or cultivars were evaluated for resistance and susceptibility to powdery mildew infection in two years under the same field conditions, and all results are summarized in Table 1. As expected, North American and European species were highly resistant and susceptible to powdery mildew infection under the same conditions, respectively, which is consistent with results of previous studies (Boubals, 1961; Olmo, 1971; Pearson and Gadoury, 1991; Li and Zhang, 1992; Wang et al., 1995; Staudt, 1997; Wang and He, 1997; Zhang et al., 2002). Some accessions of native Chinese $V$. pseudoreticulata are known to be particularly resistant to several common pathogens that infect grape plants in the Yangling area of China (He and Ren, 1990; He et al., 1991; Wang et al., 1995; Wang et al., 1998; Zhang et al., 2002; Wan et al., 2007). Of the nine accessions of V. pseudoreticulata evaluated, four showed resistance, while the rest were susceptible to powdery mildew infection. Of the resistant accessions, Baihe-35-1 displayed the strongest resistance with the lowest SI value (7.23), followed by Guangxi-1, Baihe-13-1, and Baihe-13, with SI values of 16.36, 18.67, and 18.79, respectively. Conversely, Hunan-1 was severely infected with a high SI value (67.07), which is comparable to that of $V$. vinifera, a species that is known to be the most susceptible to powdery mildew infection. We also found that all four accessions from $V$. yeshanensis, $V$. piasezkii, $V$. thunbergii, and $V$. qinlingenesis were susceptible, and all 10 accessions from the other four species, including $V$. davidii, $V$. ficifolia, $V$. quinquangularis, and $V$. amurensis showed resistance, although their SI values, an inverse indicator of resistance, were higher than that of Baihe-35-1 plants, indicating that the Baihe-35-1 line is the most resistant of all resistant wild Chinese Vitis lines evaluated.

\section{Inheritance of the powdery mildew resistant trait in $F_{1}$ and $F_{2}$ progeny of an interspecific cross between the resistant Baihe-35-1 and the susceptible Carignane parental lines}

To investigate the inheritance behavior of the identified resistant trait in the Baihe-35-1 line, Baihe-35-1 was crossed with the susceptible Carignane line, and resistance was evaluated in $\mathrm{F}_{1}$ hybrid plants. Table 2 shows that only three (6-12-4, 6-12-5, and 6-12-6) of the seven hybrid plants displayed resistance, while the rest (6-12-1, 6-12-2, 6-12-3, and 6-12-7) were susceptible to powdery mildew infection, indicating that resistance in Baihe-35-1 is not a completely dominant trait. To further analyze the resistance pattern in $\mathrm{F}_{2}$ plants, the resistant $\mathrm{F}_{1}$ line 6-12-6 $(\mathrm{SI}=23.92)$ was chosen for self-crossing, and $39 \mathrm{~F}_{2}$ plants were obtained. Table 3 shows that 26 of the 39 lines were resistant, while the rest were susceptible, representing a roughly 2:1 ratio of resistance to susceptibility. This ratio deviates from the typical 3:1 ratio of a single dominant gene phenotype segregation pattern.

Furthermore, self-crossing in the susceptible $\mathrm{F}_{1}$ lines 6-12-1 $(\mathrm{SI}=55.15)$ and 6-12-2 $(\mathrm{SI}=$ 69.93) were also performed, yielding a total of 56 and $61 \mathrm{~F}_{2}$ plants, respectively, which both showed 
a roughly 1:1 ratio of resistance to susceptibility (32:24 and 33:28) (Tables 4, 5). For the resistant $\mathrm{F}_{1}$ line 6-12-4 ( $\left.\mathrm{SI}=24.38\right), 51$ individuals were obtained from its selfing, and only one individual showed susceptibility, while the others were all resistant (Table 6). These results are not in accordance with the typical 3:1 ratio of a single dominant gene phenotype segregation pattern. Therefore,

Table 2. Resistance to powdery mildew and the demonstration of RAPD markers in $F_{1}$ individuals from Baihe-35-1 x Carignane.

\begin{tabular}{|c|c|c|c|c|c|c|}
\hline Parents and $\mathrm{F}_{1}$ individuals & Susceptibility index & Level of resistance & Phenotype & OPW02-1756 & OPO11-964 & OPY13-661 \\
\hline Baihe-35-1 & 7.23 & 3 & $\mathrm{R}$ & + & + & + \\
\hline Carignane & 49.27 & 4 & $\mathrm{~S}$ & - & - & - \\
\hline $6-12-1$ & 55.15 & 5 & HS & - & - & - \\
\hline $6-12-2$ & 69.93 & 5 & HS & - & - & - \\
\hline $6-12-3$ & 51.53 & 5 & HS & - & + & - \\
\hline $6-12-4$ & 24.38 & 3 & $\mathrm{R}$ & + & + & - \\
\hline $6-12-5$ & 22.44 & 3 & $\mathrm{R}$ & + & + & + \\
\hline $6-12-6$ & 23.92 & 3 & $\mathrm{R}$ & + & + & + \\
\hline $6-12-7$ & 44.56 & 4 & $\mathrm{~S}$ & - & + & + \\
\hline
\end{tabular}

Table 3. Resistance to powdery mildew and RAPD analysis results in the progenies from 6-12-6 selfing using the special primers.

\begin{tabular}{|c|c|c|c|c|c|c|}
\hline $\begin{array}{l}\text { Ancestor parents, parents } \\
\text { and progenies }\end{array}$ & $\begin{array}{l}\text { Susceptibility } \\
\text { index }\end{array}$ & $\begin{array}{l}\text { Level of } \\
\text { resistance }\end{array}$ & Phenotype & OPW02-1756 & OPO11-964 & OPY13-661 \\
\hline Baihe-35-1 & 7.23 & 3 & $\mathrm{R}$ & + & + & + \\
\hline Carignane & 49.27 & 4 & $\mathrm{~S}$ & - & - & - \\
\hline $6-12-6$ & 23.92 & 3 & $\mathrm{R}$ & + & + & + \\
\hline $6-1$ & 19.91 & 3 & $\mathrm{R}$ & + & + & + \\
\hline $6-2$ & 19.40 & 3 & $\mathrm{R}$ & + & + & + \\
\hline $6-4$ & 23.66 & 3 & $\mathrm{R}$ & + & + & + \\
\hline $6-5$ & 35.34 & 4 & $\mathrm{~S}$ & + & + & + \\
\hline $6-6$ & 19.68 & 3 & $\mathrm{R}$ & + & + & + \\
\hline $6-9$ & 29.50 & 4 & $\mathrm{~S}$ & + & - & - \\
\hline $6-10$ & 7.05 & 3 & $\mathrm{R}$ & + & + & + \\
\hline $6-11$ & 20.08 & 3 & $\mathrm{R}$ & + & + & + \\
\hline $6-12$ & 11.31 & 3 & $\mathrm{R}$ & + & + & + \\
\hline $6-13$ & 14.51 & 3 & $\mathrm{R}$ & + & + & - \\
\hline $6-14$ & 13.88 & 3 & $\mathrm{R}$ & + & + & + \\
\hline $6-15$ & 12.60 & 3 & $\mathrm{R}$ & + & + & - \\
\hline $6-16$ & 18.86 & 3 & $\mathrm{R}$ & - & + & + \\
\hline $6-17$ & 35.89 & 4 & $\mathrm{~S}$ & - & - & - \\
\hline $6-18$ & 24.35 & 3 & $\mathrm{R}$ & + & - & + \\
\hline $6-19$ & 7.90 & 3 & $\mathrm{R}$ & + & + & + \\
\hline $6-20$ & 32.01 & 4 & $\mathrm{~S}$ & + & - & + \\
\hline $6-21$ & 19.43 & 3 & $\mathrm{R}$ & - & - & - \\
\hline $6-22$ & 11.29 & 3 & $\mathrm{R}$ & - & - & - \\
\hline $6-24$ & 35.68 & 4 & $\mathrm{~S}$ & - & + & - \\
\hline $6-25$ & 25.81 & 4 & $\mathrm{~S}$ & - & - & - \\
\hline $6-26$ & 40.67 & 4 & $\mathrm{~S}$ & - & - & - \\
\hline $6-27$ & 17.32 & 3 & $\mathrm{R}$ & + & - & + \\
\hline $6-28$ & 25.43 & 4 & $\mathrm{~S}$ & + & + & + \\
\hline $6-29$ & 15.62 & 3 & $\mathrm{R}$ & + & + & + \\
\hline $6-30$ & 37.88 & 4 & $\mathrm{~S}$ & + & + & + \\
\hline $6-31$ & 20.61 & 3 & $\mathrm{R}$ & + & + & + \\
\hline $6-32$ & 16.67 & 3 & $\mathrm{R}$ & + & - & + \\
\hline $6-33$ & 25.99 & 4 & S & + & - & + \\
\hline $6-34$ & 22.18 & 3 & $\mathrm{R}$ & + & + & + \\
\hline $6-38$ & 31.29 & 4 & $\mathrm{~S}$ & + & - & + \\
\hline $6-39$ & 5.61 & 3 & $\mathrm{R}$ & + & + & + \\
\hline $6-40$ & 5.00 & 2 & HR & + & + & + \\
\hline $6-47$ & 15.67 & 3 & $\mathrm{R}$ & + & + & - \\
\hline $6-48$ & 25.40 & 4 & $\mathrm{~S}$ & - & + & + \\
\hline $6-49$ & 16.87 & 3 & $\mathrm{R}$ & - & + & + \\
\hline $6-50$ & 19.37 & 3 & $\mathrm{R}$ & + & + & + \\
\hline $6-51$ & 27.89 & 4 & $\mathrm{~S}$ & - & - & - \\
\hline $6-52$ & 13.81 & 3 & $\mathrm{R}$ & + & - & + \\
\hline
\end{tabular}


we suggest that resistance in Baihe-35-1 plants is controlled by multiple genes, including a major resistant gene and some minor resistant genes. Resistance in grapevine is mainly determined by the major resistant gene, and the minor resistant genes have accumulative action in hybrid progeny.

Table 4. RAPD detection results of offspring individuals from 6-12-1 selfing using the three special primers.

\begin{tabular}{|c|c|c|c|c|c|c|}
\hline $\begin{array}{l}\text { Ancestor parents, parents } \\
\text { and progenies }\end{array}$ & $\begin{array}{l}\text { Susceptibility } \\
\text { index }\end{array}$ & Level of resistance & Phenotype & OPW02-1756 & OPO11-964 & OPY13-661 \\
\hline Baihe-35-1 & 7.23 & 3 & $\mathrm{R}$ & + & + & + \\
\hline Carignane & 49.27 & 4 & S & - & - & - \\
\hline $6-12-1$ & 55.15 & 5 & HS & - & - & - \\
\hline $1-1$ & 9.04 & 3 & $\mathrm{R}$ & + & + & - \\
\hline $1-3$ & 5.25 & 3 & $\mathrm{R}$ & + & - & - \\
\hline $1-4$ & 30.04 & 4 & $\mathrm{~S}$ & + & - & - \\
\hline $1-5$ & 12.92 & 3 & $\mathrm{R}$ & - & + & - \\
\hline $1-6$ & 15.92 & 3 & $\mathrm{R}$ & + & - & - \\
\hline $1-7$ & 14.83 & 3 & $\mathrm{R}$ & + & - & - \\
\hline $1-8$ & 48.04 & 4 & $\mathrm{~S}$ & + & - & - \\
\hline $1-9$ & 9.29 & 3 & $\mathrm{R}$ & - & - & - \\
\hline $1-11$ & 14.68 & 3 & $\mathrm{R}$ & + & + & - \\
\hline $1-12$ & 23.21 & 3 & $\mathrm{R}$ & + & + & - \\
\hline $1-13$ & 8.10 & 3 & $\mathrm{R}$ & + & + & - \\
\hline $1-14$ & 13.54 & 3 & $\mathrm{R}$ & + & - & - \\
\hline $1-15$ & 28.97 & 4 & $\mathrm{~S}$ & - & - & - \\
\hline $1-16$ & 20.69 & 3 & $\mathrm{R}$ & + & - & - \\
\hline $1-17$ & 8.29 & 3 & $\mathrm{R}$ & + & - & - \\
\hline $1-18$ & 25.23 & 4 & S & - & - & - \\
\hline $1-19$ & 40.24 & 4 & S & + & - & - \\
\hline $1-20$ & 27.85 & 4 & $\mathrm{~S}$ & + & - & - \\
\hline $1-21$ & 40.21 & 4 & S & - & - & - \\
\hline $1-22$ & 13.17 & 3 & $\mathrm{R}$ & + & + & - \\
\hline $1-23$ & 8.45 & 3 & $\mathrm{R}$ & + & + & \\
\hline $1-24$ & 10.00 & 3 & $\mathrm{R}$ & - & - & - \\
\hline $1-25$ & 13.12 & 3 & $\mathrm{R}$ & + & - & - \\
\hline $1-26$ & 42.25 & 4 & $\mathrm{~S}$ & + & - & - \\
\hline $1-27$ & 30.57 & 4 & S & - & - & - \\
\hline $1-28$ & 18.37 & 3 & $\mathrm{R}$ & + & - & - \\
\hline $1-31$ & 25.12 & 4 & $\mathrm{~S}$ & - & - & - \\
\hline $1-32$ & 29.82 & 4 & $\mathrm{~S}$ & + & - & - \\
\hline $1-33$ & 33.10 & 4 & S & + & - & - \\
\hline $1-34$ & 6.13 & 3 & $\mathrm{R}$ & + & - & - \\
\hline $1-35$ & 20.86 & 3 & $\mathrm{R}$ & + & - & - \\
\hline $1-36$ & 42.71 & 4 & $\mathrm{~S}$ & - & - & - \\
\hline $1-37$ & 23.36 & 3 & $\mathrm{R}$ & + & - & - \\
\hline $1-38$ & 19.61 & 3 & $\mathrm{R}$ & - & - & - \\
\hline $1-39$ & 21.00 & 3 & $\mathrm{R}$ & + & + & - \\
\hline $1-40$ & 17.80 & 3 & $\mathrm{R}$ & + & + & - \\
\hline $1-41$ & 31.86 & 4 & $\mathrm{~S}$ & - & + & - \\
\hline $1-42$ & 41.65 & 4 & $\mathrm{~S}$ & - & - & - \\
\hline $1-43$ & 36.80 & 4 & $\mathrm{~S}$ & + & - & - \\
\hline $1-44$ & 31.40 & 4 & $\mathrm{~S}$ & - & - & - \\
\hline $1-45$ & 11.45 & 3 & $\mathrm{R}$ & + & + & - \\
\hline $1-47$ & 14.86 & 3 & $\mathrm{R}$ & + & - & - \\
\hline $1-48$ & 24.24 & 3 & $\mathrm{R}$ & - & - & - \\
\hline $1-49$ & 22.85 & 3 & $\mathrm{R}$ & + & - & - \\
\hline $1-50$ & 14.20 & 3 & $\mathrm{R}$ & - & + & - \\
\hline $1-53$ & 18.27 & 3 & $\mathrm{R}$ & - & - & - \\
\hline $1-55$ & 45.71 & 4 & $\mathrm{~S}$ & + & - & - \\
\hline $1-56$ & 31.10 & 4 & S & - & - & - \\
\hline $1-57$ & 31.53 & 4 & S & + & - & - \\
\hline $1-58$ & 16.45 & 3 & $\mathrm{R}$ & + & + & - \\
\hline $1-59$ & 40.40 & 4 & $\mathrm{~S}$ & + & - & - \\
\hline $1-60$ & 51.10 & 5 & HS & - & - & - \\
\hline $1-61$ & 15.20 & 3 & $\mathrm{R}$ & + & + & - \\
\hline $1-62$ & 28.00 & 4 & S & + & - & - \\
\hline $1-63$ & 61.82 & 5 & HS & - & - & - \\
\hline $1-64$ & 7.14 & 3 & $\mathrm{R}$ & + & + & - \\
\hline
\end{tabular}

Genetics and Molecular Research 13 (2): 3599-3614 (2014) 
Table 5. RAPD detection results of offspring individuals from 6-12-2 selfing using the three special primers.

\begin{tabular}{|c|c|c|c|c|c|c|}
\hline $\begin{array}{l}\text { Ancestor parents, parents } \\
\text { and progenies }\end{array}$ & $\begin{array}{l}\text { Susceptibility } \\
\text { index }\end{array}$ & Level of resistance & Phenotype & OPW02-1756 & OPO11-964 & OPY13-661 \\
\hline Baihe-35-1 & 7.23 & 3 & $\mathrm{R}$ & + & + & + \\
\hline Carignane & 49.27 & 4 & S & - & - & - \\
\hline $6-12-2$ & 69.93 & 5 & HS & - & - & - \\
\hline $2-1$ & 48.61 & 4 & $\mathrm{~S}$ & - & - & - \\
\hline $2-2$ & 46.29 & 4 & $\mathrm{~S}$ & - & - & - \\
\hline $2-3$ & 35.55 & 4 & $\mathrm{~S}$ & - & - & - \\
\hline $2-4$ & 46.69 & 4 & S & + & - & + \\
\hline $2-5$ & 37.68 & 4 & $\mathrm{~S}$ & - & - & - \\
\hline $2-7$ & 62.34 & 5 & HS & - & - & - \\
\hline $2-8$ & 29.83 & 4 & $\mathrm{~S}$ & - & - & - \\
\hline $2-9$ & 36.83 & 4 & $\mathrm{~S}$ & + & - & - \\
\hline $2-10$ & 59.21 & 5 & HS & + & - & - \\
\hline $2-13$ & 48.41 & 4 & $\mathrm{~S}$ & - & - & - \\
\hline $2-15$ & 48.79 & 4 & S & - & - & - \\
\hline $2-16$ & 13.50 & 3 & $\mathrm{R}$ & + & + & - \\
\hline $2-17$ & 7.02 & 3 & $\mathrm{R}$ & + & + & - \\
\hline $2-18$ & 21.00 & 3 & $\mathrm{R}$ & + & - & + \\
\hline $2-19$ & 30.06 & 4 & $\mathrm{~S}$ & + & - & + \\
\hline $2-20$ & 34.05 & 4 & $\mathrm{~S}$ & - & - & - \\
\hline $2-21$ & 42.87 & 4 & $\mathrm{~S}$ & - & + & - \\
\hline $2-22$ & 7.42 & 3 & $\mathrm{R}$ & - & + & - \\
\hline $2-23$ & 53.90 & 5 & HS & + & - & - \\
\hline $2-24$ & 38.50 & 4 & $\mathrm{~S}$ & + & + & + \\
\hline $2-25$ & 21.93 & 3 & $\mathrm{R}$ & - & - & - \\
\hline $2-30$ & 35.08 & 4 & $\mathrm{~S}$ & - & + & - \\
\hline $2-35$ & 19.57 & 3 & $\mathrm{R}$ & + & - & + \\
\hline $2-37$ & 12.24 & 3 & $\mathrm{R}$ & - & - & - \\
\hline $2-38$ & 9.67 & 3 & $\mathrm{R}$ & + & + & - \\
\hline $2-39$ & 12.70 & 3 & $\mathrm{R}$ & - & + & - \\
\hline $2-42$ & 14.81 & 3 & $\mathrm{R}$ & + & - & - \\
\hline $2-43$ & 16.60 & 3 & $\mathrm{R}$ & - & - & + \\
\hline $2-44$ & 11.46 & 3 & $\mathrm{R}$ & + & + & + \\
\hline $2-45$ & 10.43 & 3 & $\mathrm{R}$ & - & + & - \\
\hline $2-46$ & 9.32 & 3 & $\mathrm{R}$ & + & - & - \\
\hline $2-47$ & 23.50 & 3 & $\mathrm{R}$ & - & - & - \\
\hline $2-48$ & 27.65 & 4 & $\mathrm{~S}$ & - & - & - \\
\hline $2-49$ & 28.38 & 4 & $\mathrm{~S}$ & + & - & - \\
\hline $2-50$ & 14.14 & 3 & $\mathrm{R}$ & - & - & - \\
\hline $2-51$ & 12.89 & 3 & $\mathrm{R}$ & - & - & + \\
\hline $2-54$ & 26.20 & 4 & $\mathrm{~S}$ & - & + & - \\
\hline $2-55$ & 27.61 & 4 & $\mathrm{~S}$ & - & - & - \\
\hline $2-56$ & 22.58 & 3 & $\mathrm{R}$ & + & - & - \\
\hline $2-57$ & 10.85 & 3 & $\mathrm{R}$ & - & - & - \\
\hline $2-58$ & 16.17 & 3 & $\mathrm{R}$ & - & - & - \\
\hline $2-59$ & 30.09 & 4 & $\mathrm{~S}$ & - & + & - \\
\hline $2-60$ & 41.68 & 4 & $\mathrm{~S}$ & - & - & - \\
\hline $2-61$ & 21.15 & 3 & $\mathrm{R}$ & - & - & - \\
\hline $2-62$ & 35.28 & 4 & $\mathrm{~S}$ & - & - & - \\
\hline $2-63$ & 29.18 & 4 & $\mathrm{~S}$ & - & + & - \\
\hline $2-64$ & 35.31 & 4 & $\mathrm{~S}$ & - & - & - \\
\hline $2-65$ & 32.73 & 4 & $\mathrm{~S}$ & - & - & - \\
\hline $2-66$ & 19.29 & 3 & $\mathrm{R}$ & + & + & - \\
\hline $2-67$ & 24.36 & 3 & $\mathrm{R}$ & + & + & - \\
\hline $2-68$ & 14.85 & 3 & $\mathrm{R}$ & + & - & - \\
\hline $2-69$ & 22.00 & 3 & $\mathrm{R}$ & + & + & + \\
\hline $2-70$ & 27.26 & 4 & $\mathrm{~S}$ & - & - & + \\
\hline $2-71$ & 21.00 & 3 & $\mathrm{R}$ & - & - & - \\
\hline $2-72$ & 14.18 & 3 & $\mathrm{R}$ & + & - & - \\
\hline $2-73$ & 21.14 & 3 & $\mathrm{R}$ & - & - & - \\
\hline $2-74$ & 13.58 & 3 & $\mathrm{R}$ & - & + & - \\
\hline $2-75$ & 15.09 & 3 & $\mathrm{R}$ & - & - & - \\
\hline $2-76$ & 20.22 & 3 & $\mathrm{R}$ & + & - & - \\
\hline $2-77$ & 21.79 & 3 & $\mathrm{R}$ & - & - & - \\
\hline $2-78$ & 10.50 & 3 & $\mathrm{R}$ & + & - & - \\
\hline
\end{tabular}


Table 6. RAPD detection results of offspring individuals from 6-12-4 selfing using the three special primers.

\begin{tabular}{|c|c|c|c|c|c|c|}
\hline $\begin{array}{l}\text { Ancestor parents, parents } \\
\text { and progenies }\end{array}$ & $\begin{array}{l}\text { Susceptibility } \\
\text { index }\end{array}$ & Level of resistance & Phenotype & OPW02-1756 & OPO11-964 & OPY13-661 \\
\hline Baihe-35-1 & 7.23 & 3 & $\mathrm{R}$ & + & + & + \\
\hline Carignane & 49.27 & 4 & $\mathrm{~S}$ & - & - & - \\
\hline $6-12-4$ & 24.38 & 3 & $\mathrm{R}$ & + & + & - \\
\hline $4-1$ & 18.86 & 3 & $\mathrm{R}$ & + & + & - \\
\hline $4-2$ & 5.28 & 3 & $\mathrm{R}$ & - & + & - \\
\hline $4-3$ & 6.38 & 3 & $\mathrm{R}$ & + & - & - \\
\hline $4-5$ & 5.57 & 3 & $\mathrm{R}$ & - & + & - \\
\hline $4-7$ & 8.31 & 3 & $\mathrm{R}$ & + & - & - \\
\hline $4-8$ & 9.05 & 3 & $\mathrm{R}$ & + & - & - \\
\hline $4-12$ & 9.81 & 3 & $\mathrm{R}$ & + & - & - \\
\hline $4-13$ & 18.55 & 3 & $\mathrm{R}$ & + & - & - \\
\hline $4-15$ & 6.15 & 3 & $\mathrm{R}$ & - & + & - \\
\hline $4-18$ & 7.15 & 3 & $\mathrm{R}$ & + & + & - \\
\hline $4-19$ & 16.75 & 3 & $\mathrm{R}$ & + & + & - \\
\hline $4-20$ & 10.04 & 3 & $\mathrm{R}$ & + & + & - \\
\hline $4-21$ & 6.41 & 3 & $\mathrm{R}$ & + & + & - \\
\hline $4-22$ & 12.72 & 3 & $\mathrm{R}$ & - & - & - \\
\hline $4-25$ & 15.05 & 3 & $\mathrm{R}$ & - & + & - \\
\hline $4-26$ & 13.00 & 3 & $\mathrm{R}$ & + & - & - \\
\hline $4-28$ & 10.24 & 3 & $\mathrm{R}$ & - & + & - \\
\hline $4-30$ & 12.84 & 3 & $\mathrm{R}$ & + & - & - \\
\hline $4-31$ & 3.80 & 2 & HR & - & - & - \\
\hline $4-32$ & 8.57 & 3 & $\mathrm{R}$ & - & + & - \\
\hline $4-33$ & 7.00 & 3 & $\mathrm{R}$ & - & + & - \\
\hline $4-34$ & 6.79 & 3 & $\mathrm{R}$ & + & + & - \\
\hline $4-41$ & 9.41 & 3 & $\mathrm{R}$ & - & + & - \\
\hline $4-42$ & 8.76 & 3 & $\mathrm{R}$ & - & + & - \\
\hline $4-44$ & 8.86 & 3 & $\mathrm{R}$ & + & + & - \\
\hline $4-46$ & 5.68 & 3 & $\mathrm{R}$ & + & + & - \\
\hline $4-48$ & 5.89 & 3 & $\mathrm{R}$ & - & + & - \\
\hline $4-49$ & 6.72 & 3 & $\mathrm{R}$ & + & + & - \\
\hline $4-50$ & 11.51 & 3 & $\mathrm{R}$ & + & - & + \\
\hline $4-51$ & 15.81 & 3 & $\mathrm{R}$ & - & + & + \\
\hline $4-52$ & 11.28 & 3 & $\mathrm{R}$ & + & - & + \\
\hline $4-53$ & 7.64 & 3 & $\mathrm{R}$ & + & + & + \\
\hline $4-54$ & 10.98 & 3 & $\mathrm{R}$ & + & - & - \\
\hline $4-55$ & 10.61 & 3 & $\mathrm{R}$ & - & + & - \\
\hline $4-56$ & 25.57 & 4 & $\mathrm{~S}$ & - & + & - \\
\hline $4-57$ & 10.33 & 3 & $\mathrm{R}$ & + & + & - \\
\hline $4-58$ & 5.98 & 3 & $\mathrm{R}$ & - & + & - \\
\hline $4-59$ & 6.27 & 3 & $\mathrm{R}$ & + & + & - \\
\hline 4-60 & 5.71 & 3 & $\mathrm{R}$ & - & - & + \\
\hline 4-61 & 6.47 & 3 & $\mathrm{R}$ & - & + & - \\
\hline 4-62 & 6.75 & 3 & $\mathrm{R}$ & + & + & - \\
\hline 4-64 & 5.36 & 3 & $\mathrm{R}$ & - & + & - \\
\hline $4-65$ & 10.36 & 3 & $\mathrm{R}$ & - & - & - \\
\hline $4-72$ & 9.20 & 3 & $\mathrm{R}$ & - & - & - \\
\hline $4-75$ & 20.44 & 3 & $\mathrm{R}$ & + & - & - \\
\hline $4-76$ & 14.44 & 3 & $\mathrm{R}$ & + & + & + \\
\hline $4-78$ & 6.96 & 3 & $\mathrm{R}$ & + & + & - \\
\hline $4-81$ & 4.73 & 2 & HR & - & + & + \\
\hline $4-82$ & 4.85 & 2 & HR & + & + & - \\
\hline $4-83$ & 7.40 & 3 & $\mathrm{R}$ & - & - & - \\
\hline 4-84 & 18.00 & 3 & $\mathrm{R}$ & + & - & - \\
\hline
\end{tabular}

Identification of RAPD markers associated with the powdery mildew-resistant trait in wild Chinese Vitis

Of the 520 random primers screened, at least three primers, OPW02 
(5'-ACCCCGCCAA-3'), OPO11 (5'-GACAGGAGGT-3'), and OPY13 (5'-GGGTCTCGGT-3'), were found to be associated with the resistant trait in Baihe-35-1, as well as in some other Chinese Vitis species. As shown in Table 1, these markers could amplify a specific DNA fragment size in Baihe-35-1 plants and in some other resistant wild Chinese Vitis species, but not in any of the four susceptible Chinese and European lines. This result suggested that these markers are specifically associated with powdery mildew resistance in wild Chinese Vitis Baihe-35-1 and some other accessions. In $\mathrm{F}_{1}$ progenies derived from the cross between Baihe-35-1 and Carignane, the OPW02 primer amplified a specific 1756-bp band from three resistant lines (6-12-4, 6-12-5, and 6-12-6), but not in the susceptible lines (6-12-1, 6-122, 6-12-3, and 6-12-7) (Table 2, Figure 1). A similar association was also found using the OPO11-964 and OPY13-661 markers that could amplify DNA fragments in parental and $\mathrm{F}_{1}$ resistant lines, as well as in some of the susceptible $\mathrm{F}_{1}$ lines (Table 2, Figures 2, 3), indicating that all three RAPD markers tested are generally linked to the powdery resistant trait in the Baihe-35-1 accession or clones. DNA cloning and sequencing analyses showed that none of the three DNA fragments amplified by the individual RAPD analysis had any relationship to sequences of genes involved in disease resistance.

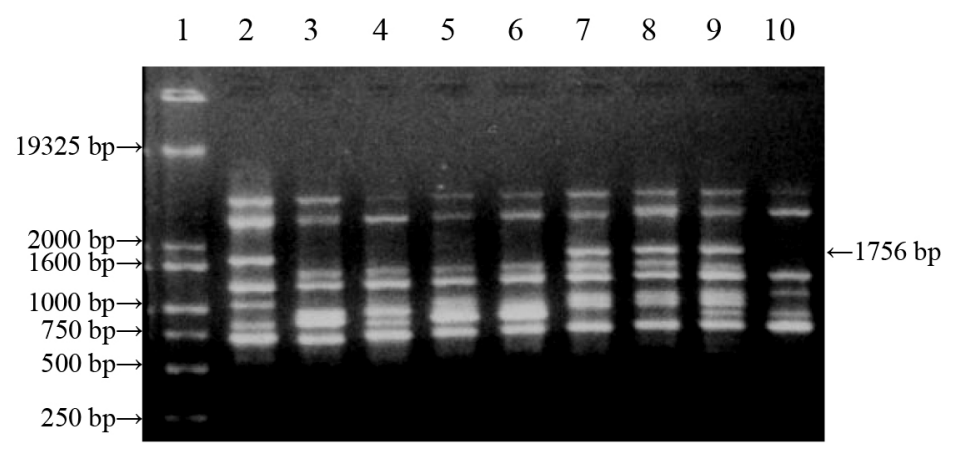

Figure 1. Schematics of RAPD products obtained from parents and $\mathrm{F}_{1}$ individuals of Baihe-35-1 x Carignane using RAPD primer OPW02.

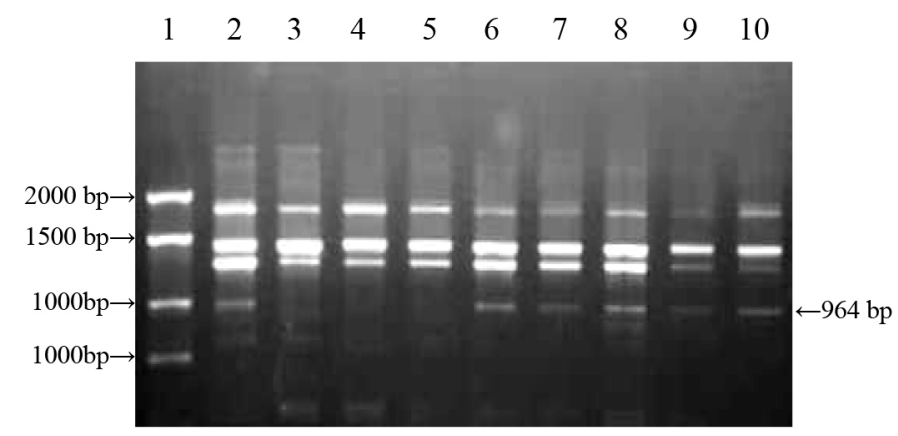

Figure 2. Schematics of RAPD amplification products from parents and $F_{1}$ individuals of combination Baihe-35-1 $\mathrm{x}$ Carignane using RAPD primer OPO11. 


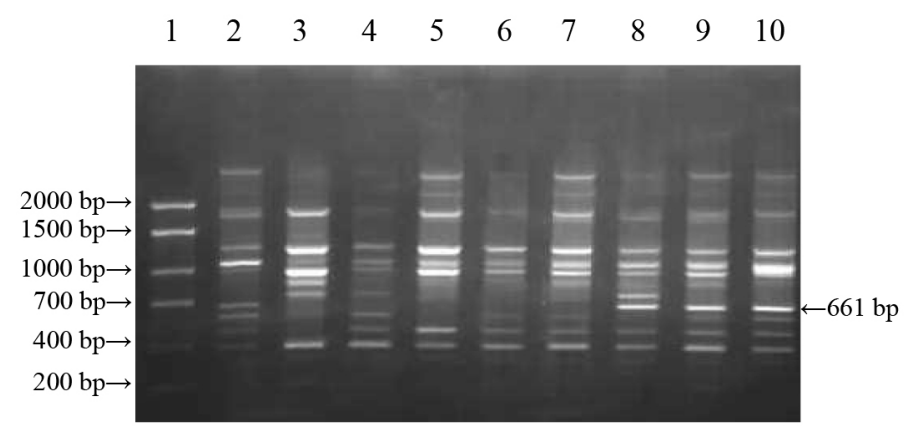

Figure 3. Schematics of RAPD amplification products from parents and $F_{1}$ individuals of combination Baihe-35-1 x Carignane using RAPD primer OPY13.

To further verify this linkage, $39 \mathrm{~F}_{2}$ progenies from the self-crossing of the resistant 6-12-6 $\mathrm{F}_{1}$ line were subjected to the same RAPD analyses as described above. We found that 22 of the 26 resistant plants, and 7 of the 13 susceptible lines gave the OPW02-1756 marker pattern, corresponding to the 1756-bp fragment (Table 3, Figure 4). Twenty-one of the 26 resistant plants, and 5 of the 13 susceptible lines yielded the OPO11-964 marker band corresponding to a 964-bp fragment (Table 3, Figure 5), and 22 of the 26 resistant plants, and 7 of the 13 susceptible lines generated the OPY13-661 marker band corresponding to a 661-bp fragment (Table 3 , Figure 6). These results again strongly suggested that all three markers were linked to the resistant gene(s) in Baihe-35-1 plants. This suggestion was further confirmed by linkage analysis using the Joinmap program. The markers OPW02-1756 and OPY13-661 were found to link together and were located $22.2 \mathrm{cM}$ away from the resistance gene on one side, while the marker OPO11-964 was located at a similar distance to the resistant gene, but on the opposite side.

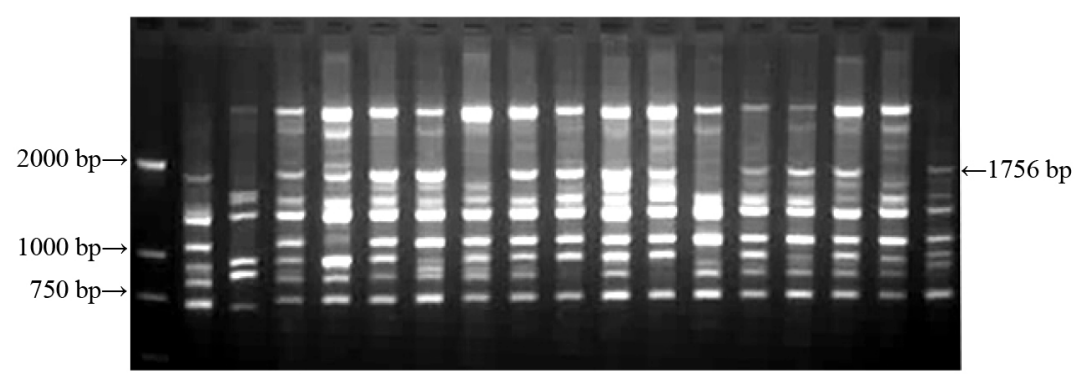

Figure 4. Schematics of RAPD amplification products from individuals of 6-12-6 self-pollination using RAPD primer OPW02.

\section{Detection of the identified RAPD markers for powdery mildew resistance in interspecific hybrid $\mathrm{F}_{2}$ progeny}

The linkage of the identified three markers provides a great utility for selection and 
breeding for powdery mildew resistance in progenies of genetic crossing programs. To test this utility, we self-crossed three $\mathrm{F}_{1}$ lines, including 6-12-1, 6-12-2, and 6-12-4, and a total of 168 $\mathrm{F}_{2}$ individuals were obtained. One hundred fifteen of the 168 individuals demonstrated resistance to powdery mildew under natural field conditions. We found that four of the 115 resistant individuals carried all three RAPD markers, 36 individuals carried two of the markers, and 53 possessed only one of the three markers (Tables 4, 5, and 6). This indicated that 93 resistant individuals possessed the RAPD markers, whereas the remaining 22 resistant individuals and 27 of the 53 susceptible individuals had none of the three markers. This pattern might have been due to chromosome exchange during pairing between male and female gametes.

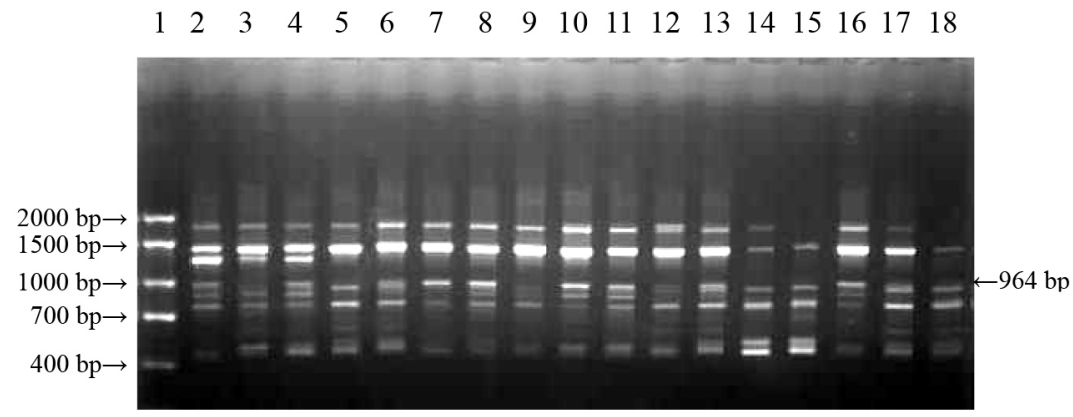

Figure 5. Schematics of RAPD amplification products from individuals of 6-12-6 self-pollination using RAPD primer OPO11.

$\begin{array}{llllllllllllllllll}1 & 2 & 3 & 4 & 5 & 6 & 7 & 8 & 9 & 10 & 11 & 12 & 13 & 14 & 15 & 16 & 17 & 18\end{array}$

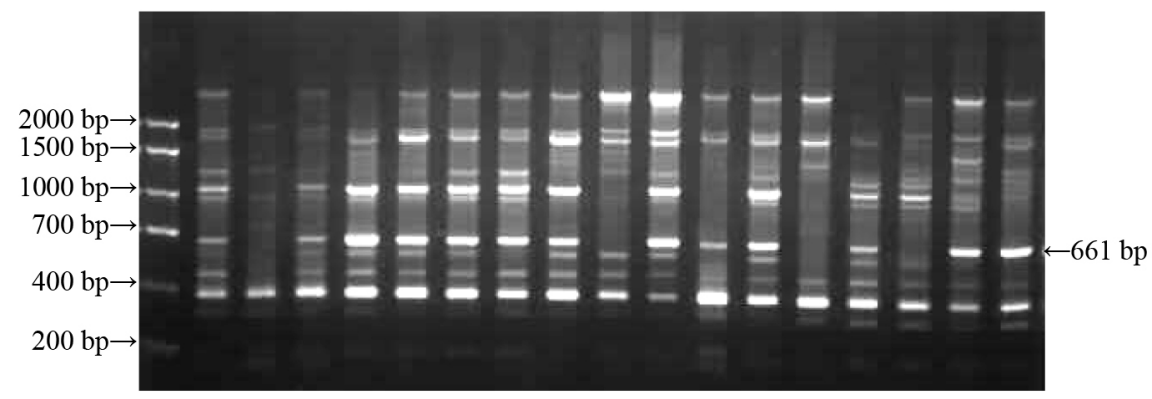

Figure 6. Schematics of RAPD amplification products from individuals of 6-12-6 self-pollination using RAPD primer OPY13.

\section{DISCUSSION}

Characterization of powdery mildew resistance in grape germplasm have been extensively reported, and powdery mildew-resistant traits were found to have independently evolved in North American and Chinese species, but not in European species (Boubals, 1961; Olmo, 1971; Bouquet, 1980; Roy and Ramming, 1990; He et al., 1991; Li and Zhang, 1992; Honrao et al., 1992; Wang et al., 1995; Staudt, 1997; Kozma, 2000; Zhang et al., 2002; Fischer 
et al., 2004; Wan et al., 2007). Consistent with these findings, we also observed that only Chinese and North American, but not European, species showed resistance to powdery mildew disease to various degrees in plants grown in the same location over two consecutive years (Table 1), indicating that resistance persists in various climates, and is therefore likely determined by genetic factors. Interestingly, North American species appear to generally confer much stronger resistance to powdery mildew infection compared to Chinese species. Some North American species, such as $V$. rotundifolia, were completely resistant, as evidenced by a zero SI index value, whereas Baihe-35-1, the most strongly resistant line among Chinese species, remains susceptible to the infection to some extent with an SI index value as high as 7.23 (Table 1). Whether North American and Chinese species share similar or different resistance mechanisms remains unknown. The fact that three RAPD markers were found to be associated with resistant genes only in the Chinese species Baihe-35-1 suggests that the particular resistant genes or mechanisms evolved might be different between North American and Chinese species. However, the possibility that the diverged genome sequences of North American and Chinese species may contribute to differential detection of the three markers cannot be excluded. Hence, further molecular and genetic analyses would provide insight into understanding the evolution of resistance mechanisms in different Vitis species.

Previous studies have shown that $V$. pseudoreticulata distributed across eastern and southern China confers broad resistance to various fungal diseases, such as Plasmopara viticola, Sphaceloma ampelinum, U. necator, and Glomerella cingulata (He et al., 1991; Wang et al., 1995; Wang et al., 1998; Zhang et al., 2002; Wan et al., 2007). The present study also demonstrated that at least four of the nine accessions tested were barely infected by the powdery mildew under natural conditions, indicating that $V$. pseudoreticulata species have acquired resistance to the powdery mildew pathogen. We also found that not all of the $V$. pseudoreticulata accessions were resistant, and five of the nine were susceptible. In particular, Hunan-1, one of the nine accessions, was extremely susceptible at a level comparable to that of European cultivars such as Jingkejing or Black Rose (Table 1). This result is not completely consistent with those of Wan et al. (2007).

Powdery mildew resistance was shown to be controlled by genetic factors. Previous research showed that the resistant behavior was a qualitative genetic trait that was presumably controlled by a single dominant gene. For example, Filippenko and Shtin (1975) studied the inheritance of powdery mildew resistance in hybrids of $V$. vinifera $\mathrm{x} V$. amurensis. Bouquet (1980) investigated powdery mildew resistance in the Vitis subgenus Muscadine. Resistance to powdery mildew in Muscadinia rotundifolia was mapped to the single dominant locus Run 1 (Barker et al., 2005; Dry et al., 2009), and was also mapped to a single dominant locus, REN1 in the Central Asian $V$. vinifera variety 'Kishmish vatkana' (Hoffmann et al., 2008). Another study suggested that resistance in $V$. amurensis and $V$. labrusca species was controlled by a dominant gene (Kozma, 2000), while similar analyses showed that although resistance in Chinese Vitis species behaved in a dominant independent inheritance pattern, it was most likely controlled by a couple of genes (Wang and He, 1997). It is generally believed that powdery mildew resistance is controlled by quantitative genes (Boubals, 1961; Li and Zhang, 1992; Honrao et al., 1992; Eibach, 2000; Dalbó et al., 2001). The present analysis on resistance inheritance patterns in $\mathrm{F}_{1}$ and $\mathrm{F}_{2}$ progeny of the same cross favors a major dominant gene control mechanism since $\mathrm{F}_{1}$ progenies of the Baihe-35-1 and Carigane cross displayed a close 1:1 ratio of resistance to susceptibility, and $\mathrm{F}_{2}$ progenies of the same cross followed a roughly 2:1 
ratio of resistance to susceptibility (Tables 2,3 ), indicating that more than one gene is likely involved in the regulation of resistance in Baihe-35-1 plants.

Dominant inheritance of powdery mildew resistance in Baihe-35-1 plants would facilitate the development of genetic and molecular markers for gene mapping and association, as well as for marker-assisted selection and breeding. One of the most powerful mapping strategies is bulked segregant analysis (BSA) (Michelmore et al., 1991), which is an efficient method for mapping resistance genes in highly heterozygous fruit trees. The BSA method requires the construction of resistant and susceptible pools, respectively, based on the segregation of resistance genes in the $\mathrm{F}_{2}$ generation. In the present study, construction of such pools was limited due to the low number of $F_{1}$ individuals. Therefore, we selected the $F_{1}$ resistant 6-12-6 and susceptible 6-12-2 lines, as well as both of their parental lines for primer selection. Three potential candidate RAPD markers, OPW02-1756, OPO11-964, and OPY13-661, that were potentially associated with powdery mildew resistance, were initially obtained through screening over 500 random primers. Analyses in parental, $\mathrm{F}_{1}$, and $\mathrm{F}_{2}$ progenies revealed that the markers were located approximately $22 \mathrm{cM}$ away from the powdery mildew resistance gene in Baihe-35-1 plants on either side. Practical applications of these markers for marker-assisted selection during breeding were also investigated in several crosses. $\mathrm{F}_{2}$ progenies associated with one, two, or all three markers were successfully identified (Tables 4, 5, 6), and these selected lines will expedite the breeding process, especially during the early stage of breeding.

\section{ACKNOWLEDGMENTS}

Research supported by the National Natural Foundation of the People's Republic of China (Grant \#31171924), and the National Sci-tech Support Plan (\#2013BAD02B00). The manuscript was revised by Dr. Zongrang Liu (USDA-ARS-AFRS).

\section{REFERENCES}

Akkurt M, Welter L, Maul E, Töpfer R, et al. (2007). Development of SCAR markers linked to powdery mildew (Uncinula necator) resistance in grapevine (Vitis vinifera L. and Vitis sp.). Mol. Breed. 19: 103-111.

Alleweldt G, Spiegel-Roy P and Reisch BI (1990). Grape (Vitis). In: Genetic Resources of Temperate Fruit and Nut Crops (Moore JN and Ballington JR, eds.), Madison. 291-337.

Barker CL, Donald T, Pauquet J, Ratnaparkhe MB, et al. (2005). Genetic and physical mapping of the grapevine powdery mildew resistance gene, Run1, using a bacterial artificial chromosome library. Theor. Appl. Genet. 111: 370-377.

Belhadj A, Telef N, Cluzet S, Bouscaut J, et al. (2008). Ethephon elicits protection against Erysiphe necator in grapevine. J. Agric. Food Chem. 56: 5781-5787.

Boubals DA (1961). Study of the factors responsible for the resistance of Vitaceae to grapevine powdery mildew ( $U$. necator Schw. Burr.) and their mode of inheritance. Plant Breed. Abstracts 32: 946.

Bouquet A (1980). Vitis X Muscadinia hybridization as a method of introducing resistance characters into cultivated vine by introgression, and cytogenetic and taxonomic problems in presents. Plant Breed. Abstracts 51: 320.

Dalbó MA, Ye GN, Weeden NF, Wilcox WF, et al. (2001). Marker-assisted selection for powdery mildew resistance in grapes. J. Am. Soc. Hortic. Sci. 126: 83-89.

Dry IB, Feechan A, Anderson C, Jermakow AM, et al. (2009). Molecular strategies to enhance the genetic resistance of grapevines to powdery mildew. Aust. J. Grape Wine Res. 16: 94-105.

Eibach R (2000). Investigations on the inheritance of resistance features to mildew diseases. Acta Hortic. 528: 455-465.

Ercisli S, Orhan E, Hizarci Y, Yildirim N, et al. (2008). Genetic diversity in grapevine germplasm resources in the Coruh valley revealed by RAPD markers. Biochem. Genet. 46: 590-597.

Filippenko IM and Shtin LT (1975). Inheritance of resistance to downy and powdery mildew in hybrids of European vines with Vitis amurensis. Plant Breed. Abstracts 45: 677.

Fischer BM, Salakhutdinov I, Akkurt M, Eibach R, et al. (2004). Quantitative trait locus analysis of fungal disease 
resistance factors on a molecular map of grapevine. Theor. Appl. Genet. 108: 501-515.

Gee LM, Stummer BE, Gadoury DM, Biggins LT, et al. (2000). Maturation of cleistothecia of Uncinula necator (powdery mildew) and release of ascospores in southern Australia. Aust. J. Grape Wine Res. 6: 13-20.

He PC and Ren ZB (1990). Study on the resistance of wild Vitis species native to China to grape ripe rot. J. Fruit Sci. 7 : 7-12.

He PC and Lou GG (1994). Grape Science. China Agriculture Press, Beijing.

He PC, Wang YJ, Wang GY, Ren ZB, et al. (1991). The studies on the disease-resistance of Vitis wild species originated in China. Sci. Agric. Sin. 24: 50-56.

Hoffmann S, Di Gaspero G, Kovács L, Howard S, et al. (2008). Resistance to Erysiphe necator in the grapevine 'Kishmish vatkana' is controlled by a single locus through restriction of hyphal growth. Theor. Appl. Genet. 116: 427-438.

Honrao BK, Patil SG, Rao VG and Patil VP (1992). Note on screening of grape hybrids for resistance to powdery mildew. Indian J. Hortic. 49: 253-255.

Kozma PJ (2000). Winery grape breeding for fungus disease resistance. Acta Hortic. 2: 505-510.

Li H and Zhang ZW (1992). Study on resistance and stability to U. necator in V. vinifera L. Acta Hortic. Sin. 19: 23-28.

Lu J, Schell L and Ramming DW (2000). Interspecific hybridization between Vitis rotundifolia and Vitis vinifera and evaluation of the hybrids. Acta Hortic. 2: 479-486.

Luo S, He P, Zheng X and Zhou P (2002). Inheritance of RAPD markers in an interspecific $\mathrm{F}_{1}$ hybrid of grape between Vitis quinquangularis and V. vinifera. Sci. Hortic. 93: 19-28.

Michelmore RW, Paran I and Kesseli RV (1991). Identification of markers linked to disease-resistance genes by bulked segregant analysis: a rapid method to detect markers in specific genomic regions by using segregating populations. Proc. Natl. Acad. Sci. U. S. A. 88: 9828-9832.

Olmo HP (1971). Vinifera rotundifolia hybrids as wine grapes. Am. J. Enol. Vitic. 22: 87-91.

Pauquet J, Bouquet A, This P and Adam-Blondon A-F (2001). Establishment of a local map of AFLP marker around the powdery mildew resistance gene Run 1 in grapevine and assessment of their usefulness for marker assisted selection. Theor. Appl. Genet. 103: 1201-1210.

Pearson RC and Gadoury DM (1991). Powdery Mildew of Grape. In: Plant Diseases of International Importance: Diseases of Fruit Crops, Vol. III (Kumar J, Chaube HS, Singh US and Mukhopadhyay AN, eds.). Prentice Hall, Englewood Cliffs, NJ, 129-146.

Reisch BI and Pratt C (1996). Grapes. In: Fruit Breeding. Vine and Small Fruit Crops. Wiley, New York (Janick J and Moore JN, eds.). 197-369.

Roy RR and Ramming DW (1990). Varietal resistance of grape to the powdery mildew fungus, Uncinula necator. Fruit Varieties J. 44: 149-155.

Staudt G (1997). Evaluation of resistance to grapevine powdery mildew (Uncinula necator [Schw.] Burr, anamorph Oidium tuckeri Berk.) in accessions of Vitis species. Vitis 36: 151-154.

Wan Y, Schwaninger H, He P and Wang Y (2007). Comparison of resistance to powdery mildew and downy mildew in Chinese wild grapes. Vitis 46: 132-136.

Wang Y and He P (1997). Study on the inheritance of resistance to powdery mildew in Chinese native wild Vitis L. species. Sci. Agric. Sin. 30: 19-25.

Wang Y, Liu Y and He P (1998). Resistance of Chinese Vitis species to Elsinoë ampelina (de Bary) Shear. HortScience 33: 123-126.

Wang Y, Liu Y, He P, Chen J, et al. (1995). Evaluation of foliar resistance to Uncinula necator in Chinese wild Vitis species. Vitis 34: 159-164.

Wang YJ, Lamikanra O, Lu J and Ramming DW (1996). Identification of genetic marker linked to seedless gene in grapes using RAPD. Acta Univ. Agric. Boreali-Occidentalis 24: 1-10.

Weeden NF, Hemmat M, Lawson DM, Lodhi M, et al. (1994). Development and application of molecular marker linkage maps in woody fruit crops. Euphytic 77: 71-75.

Zhang JX, Wang YJ and Xu Y (2002). The resistance of Chinese wild Vitis to Uncinula necator and its inheritance in $\mathrm{F}_{1}$ generation. Agric. Sci. China 1: 195-199. 